\title{
Fetal and neonatal nicotine exposure and postnatal glucose homeostasis: identifying critical windows of exposure
}

\author{
Jennifer E Bruin, Lisa D Kellenberger, Hertzel C Gerstein ${ }^{1}$, Katherine M Morrison ${ }^{2}$ and Alison C Holloway \\ Reproductive Biology Division, Department of Obstetrics and Gynecology, McMaster University, RM HSC-3N52, 1200 Main Street West, Hamilton, Ontario, \\ Canada L8N $3 Z 5$ \\ Departments of ${ }^{1}$ Medicine and ${ }^{2}$ Pediatrics, McMaster University, Hamilton, Ontario, Canada L8N 3Z5 \\ (Requests for offprints should be addressed to A C Holloway; Email: hollow@mcmaster.ca)
}

\begin{abstract}
Fetal and lactational exposure to nicotine at concentrations comparable with those in women who smoke causes impaired glucose tolerance in male offspring in postnatal life. It remains unknown whether there are critical windows of susceptibility to nicotine exposure. Female nulliparous Wistar rats were given saline vehicle or nicotine bitartrate $(1 \mathrm{mg} / \mathrm{kg}$ per day) prior to pregnancy, which was then: A) discontinued during pregnancy and lactation; B) continued until parturition; C) continued until weaning; and D) discontinued during pregnancy and restarted from lactation until weaning. At 26 weeks of age, offspring in each group were challenged with an oral glucose load. $\beta$-Cell mass, apoptosis, and proliferation were measured at birth, and at 4 and 26 weeks of age. The animals in group $\mathrm{C}$ (exposed to nicotine throughout
\end{abstract}

pregnancy and lactation) had reduced $\beta$-cell mass from birth through 26 weeks of age and impaired glucose homeostasis at 26 weeks of age. $\beta$-Cell mass was also reduced at birth and at 4 weeks of age in animals exposed to nicotine during pregnancy alone (group B). However, enhanced proliferation following weaning led to recovery of this defect to $98 \%$ of control levels by week 26 . The response to the glucose load in groups A, B, and $\mathrm{D}$ did not differ from controls. Continued exposure to nicotine from conception through lactation results in permanent $\beta$-cell loss and subsequent impaired glucose tolerance. This model of type 2 diabetes requires that nicotine exposure occurs both in utero and during lactation.

Journal of Endocrinology (2007) 194, 171-178

\section{Introduction}

Approximately 15-20\% of all women smoke while pregnant (Andres \& Day 2000, Bergmann et al. 2003), despite intentions to refrain from smoking during that period (Okuyemi et al. 2000). Cigarette smoking during pregnancy remains one of the most important modifiable risk factors for adverse fetal, obstetrical, and developmental outcomes (Andres \& Day 2000, Hofhuis et al. 2003). Moreover, epidemiological studies have demonstrated that fetal exposure to maternal smoking during pregnancy is associated with adverse postnatal health outcomes, including obesity, hypertension, and type 2 diabetes (Morley et al. 1995, Vik et al. 1996, Blake et al. 2000, Montgomery \& Ekbom 2002, Toschke et al. 2002, Von et al. 2002, Bergmann et al. 2003, Wideroe et al. 2003). In pregnant women who smoke or use nicotine-replacement therapy, nicotine crosses the placenta, concentrates in fetal blood and amniotic fluid, and is detectable in breast milk during lactation (Lambers \& Clark 1996). Therefore, maternal nicotine exposure results in both fetal and neonatal exposure.

Animal studies have demonstrated that fetal and neonatal exposure to nicotine alone, at levels that are representative of women who smoke or use nicotine replacement therapy, results in low birth weight, and postnatal impaired glucose homeostasis, hyperinsulinemia, increased body weight and dyslipidemia (Williams \& Kanagasabai 1984, Newman et al. 1999, Pausova et al. 2003, Gao et al. 2005, Holloway et al. 2005). The $\beta$-cell loss, impaired glucose tolerance, and hyperinsulinemia observed in the nicotine-exposed offspring from this animal model (Holloway et al. 2005) closely represent symptoms associated with type 2 diabetes in humans (Pratley \& Weyer 2001, Leahy 2005). However, the heterogeneous nature of smoking behavior and nicotine replacement therapy use in the pregnant and breastfeeding population (McBride \& Pirie 1990, Castrucci et al. 2006, Thyrian et al. 2006) results in nicotine exposures during different windows of development. Epidemiological evidence strongly suggests that cessation or at least reduction of cigarette smoking during pregnancy will ameliorate the damage to a developing fetus (Lindley et al. 2000, Pickett et al. 2003); however, the effect of smoking cessation on metabolic disturbances in the offspring has not yet been determined. Furthermore, the developmental stages when nicotine exposure can result in an irreversible impact on glucose homeostasis in the offspring have not yet been identified. This study was designed to identify critical windows of fetal and neonatal exposure to maternal nicotine 
on the development of the pancreatic $\beta$-cell and glucose intolerance in the offspring.

\section{Materials and Methods}

\section{Maintenance and treatment of animals}

All animal experiments were approved by the Animal Research Ethics Board at McMaster University, in accordance with the guidelines of the Canadian Council for Animal Care. Nulliparous, 200-250 g female Wistar rats (Harlan, Indianapolis, IN, USA) were maintained under controlled lighting (12 h light:12 h darkness) and temperature $\left(22^{\circ} \mathrm{C}\right)$ with food and water available ad libitum. Dams were randomly assigned $(n=5$ per group) to receive saline (vehicle) or nicotine bitartrate (1 mg/kg per day; Sigma-Aldrich) via s.c. injection daily: A) for 2 weeks prior to mating only; B) for 2 weeks prior to mating until parturition (fetal exposure); C) for 2 weeks prior to mating until weaning (fetal and neonatal exposure); and D) for 2 weeks prior to mating and after parturition until weaning (neonatal exposure).

At postnatal day (PND) 1, litters were culled to eight, retaining males in preference to assure uniformity of litter size between treated and control litters. To eliminate any confounding effects of the female reproductive cycle, only male offspring were used in this study. After weaning at PND21, male offspring were selected randomly and caged as sibling pairs.

\section{Oral glucose tolerance}

Glucose homeostasis was investigated in nicotine-exposed and control rats at 26 weeks of age ( $n=12$ per group) using an oral glucose tolerance test (OGTT). To avoid litter effects, no more than three animals from a single litter were tested. After an overnight fast, serum concentrations of insulin and glucose were measured in saphenous vein samples, collected by repeated puncture, at baseline $(0900 \mathrm{~h}), 30$ and $120 \mathrm{~min}$ after rats were given $2 \mathrm{~g} / \mathrm{kg}$ glucose (Sigma-Aldrich) in water by gavage as previously described (Cleasby et al. 2003). Blood samples were allowed to clot at $4{ }^{\circ} \mathrm{C}$, centrifuged, and stored at $-80^{\circ} \mathrm{C}$ until assayed. Serum glucose concentrations were measured by a commercially available kit using the glucose oxidase method (Pointe Scientific Inc., Canton, MI, USA), and insulin levels were measured by an ultra-sensitive rat insulin ELISA (Crystal Chem Inc., Downers Grove, IL, USA).

\section{$\beta$-Cell mass}

To assess whether nicotine exposure during pregnancy and lactation alters prenatal and postnatal development of pancreas, pancreatic tissue was collected from a subset of pups at birth (PND1), and at 4 and 26 weeks of age. Animals at PND1 were killed by decapitation, and those at 4 and 26 weeks of age were killed by isofluorane overdose. The pancreas from each animal was weighed and then fixed by immersion in $10 \%(\mathrm{v} / \mathrm{v})$ neutral buffered formalin (EM Science, Gibbstown, NJ, USA) at $4{ }^{\circ} \mathrm{C}$ overnight, washed in water, and embedded in paraffin. Immunohistochemical detection of insulin was performed on $5 \mu \mathrm{m}$ serial sections, separated by an average of $30 \mu \mathrm{m}$, of PND1, week 4 and week 26 pancreatic tissues from salineexposed (five sections per animal; five animals randomly selected to include animals from each saline exposure group) and nicotine-exposed (five sections per animal; five animals per group) offspring. These age groups were selected to examine the effects of nicotine exposure on fetal pancreatic development (PND1), neonatal pancreatic development (week 4), and adult pancreatic development (week 26). Tissue sections were deparaffinized in xylene, rehydrated, and washed in PBS. Endogenous peroxidase activity was quenched in methanol, followed by antigen retrieval in $10 \mathrm{mmol} / \mathrm{l}$ citrate buffer $(\mathrm{pH}$ $3 \cdot 0)$ and blocking with $10 \%(\mathrm{v} / \mathrm{v})$ normal goat serum and $1 \%$ $(\mathrm{w} / \mathrm{v})$ BSA. Sections were then incubated with the primary antibody, a polyclonal, guinea pig anti-swine insulin antibody (1:150 dilution; DakoCytomation, Carpinteria, CA, USA), which has been shown by the manufacturer to cross-react with rat insulin, overnight at $4{ }^{\circ} \mathrm{C}$. Sections were then washed in PBS, and immunostaining was identified using the Vectastain kit (Vector Laboratories, Burlinghame, CA, USA), with diaminobenzidine as the chromogen. Tissue sections were counterstained with Harris' hematoxylin, destained with acid alcohol, dehydrated and mounted with Permount (Fisher Scientific, Fair Lawn, NJ, USA). Control sections were incubated with $1 \%(\mathrm{w} / \mathrm{v}) \mathrm{BSA}$ in PBS in place of the primary antibody. In all sections, the whole pancreas was analyzed by combining measurements from up to 90 fields per section. Immunopositive cells were identified using Image Pro Plus v. 5.1 software (Media Cybernetics Inc., Silver Spring, MD, USA) for automated cell counting and the calculation of $\beta$-cell area and total pancreas area. The percent $\beta$-cell area was calculated as a ratio of the $\beta$-cell area (immunopositive staining only) to the total pancreas area (immunopositive staining and pancreas counterstaining) $\times 100$. The $\beta$-cell mass was calculated as the product of the percent $\beta$-cell area and the corresponding total pancreas weight in milligrams.

\section{Islet apoptosis and proliferation}

Detection of apoptotic cells in pancreatic islets from salineand nicotine-treated rats was performed using a terminal deoxynucleotidyl transferase-mediated dUTP nick end labeling (TUNEL) assay according to manufacturer's instructions (Roche Applied Science) with insulin colocalization. Briefly, tissue sections were deparaffinized in xylene and rehydrated in decreasing concentrations of ethanol to PBS. Next, tissues were subjected to antigen retrieval in $10 \mathrm{mmol} / 1$ citrate buffer $(\mathrm{pH} \mathrm{3.0)}$ and blocking with 10\% (v/v) normal goat serum and $1 \%(\mathrm{w} / \mathrm{v})$ BSA. Sections were then incubated with the primary antibody, a polyclonal, guinea pig antiswine insulin antibody (1:150 dilution; DakoCytomation), overnight at $4{ }^{\circ} \mathrm{C}$ followed by anti-rabbit Alexa Fluor 594 secondary antibody (1:400 dilution; Molecular Probes Inc., 
Eugene, OR, USA) for $2 \mathrm{~h}$ at room temperature. Following the immunofluorescence immunostaining for insulin, tissues were subjected to the TUNEL assay. Following a PBS wash, tissues were permeabilized in $0.5 \%(\mathrm{v} / \mathrm{v})$ Triton X-100 for $30 \mathrm{~min}$ at room temperature and then incubated with the fluorescein isothiocyanate(FITC)-conjugated TUNEL enzyme for $60 \mathrm{~min}$ to detect DNA fragmentation. Nuclei were counterstained with 4,6-diamidino-2-phenylindole (DAPI) (Sigma-Aldrich) and tissue sections were imaged with an Olympus BX-61 microscope and analyzed with Image Pro Plus v. 5.1 software (Media Cybernetics Inc.). For analysis, three islets per section (three sections per animal; five animals per group) were quantified for apoptosis and reported as the percentage of $\mathrm{TUNEL}^{+} \beta$-cells.

To evaluate islet cell proliferation, tissues were processed as above and incubated with a mouse anti-proliferating cell nuclear antigen (PCNA) antibody (1:2000 dilution; SigmaAldrich) overnight at $4{ }^{\circ} \mathrm{C}$. PCNA has been demonstrated to be a useful marker of islet cell proliferation, as it is present in the cell nuclei within the later part of G1, S, and G2 phases of the cell cycle (Petrik et al. 1999). Immunostaining was identified using the Vectastain kit (Vector Laboratories), with diaminobenzidine as the chromogen. Tissue sections were counterstained with Harris' hematoxylin, destained with acid alcohol, and dehydrated and mounted with Permount (Fisher Scientific). For analysis, three islets per section (three sections per animal; five animals per group) were quantified. Islet cell proliferation was assessed as the percentage of total islet cells that were $\mathrm{PCNA}^{+}$.

\section{Statistical analysis}

All statistical analyses were performed using SigmaStat (v. 2.03; SPSS, Chicago, IL, USA) and one-way ANOVA followed by post hoc multiple comparisons when significance was indicated by ANOVA $(\alpha=0 \cdot 05)$. When significance was indicated by ANOVA, OGTT results for each treatment group were compared with the saline controls (Bonferroni's $t$ test, $\alpha=0 \cdot 05)$. There was no difference in the glucose or insulin response to the OGTT at baseline, 30, or $120 \mathrm{~min}$ among the four saline groups (one-way ANOVA; all $P>$ $0 \cdot 90)$, so the data were pooled for comparison with the nicotine-exposed offspring. Similarly, there were no differences in $\beta$-cell mass, apoptosis, or proliferation among the four saline groups (one-way ANOVA; all $P>0 \cdot 90$ ), so the results for the saline-exposed groups were pooled for comparison with the nicotine-exposed offspring. When significance was indicated by ANOVA $(P<0 \cdot 05)$, the results for $\beta$-cell mass, proliferation, and apoptosis among each treatment group were compared with each other using the Student-Neuman-Keuls test. The data were tested for normality as well as equal variance, and when normality or variance tests failed, data were analyzed using Kruskal-Wallis one-way ANOVA on ranks. The area under the curve (AUC) for the total glucose response during the OGTT was assessed using the trapezoidal rule.

\section{Results}

\section{Pregnancy outcome and birth phenotypes}

Nicotine administration had no effect on maternal food consumption during the 2 -week period prior to mating (saline $8 \cdot 5 \pm 0 \cdot 24 \mathrm{~g}$ food $/ 100 \mathrm{~g}$ body weight versus nicotine $8 \cdot 9 \pm 0 \cdot 30 \mathrm{~g}$ food $/ 100 \mathrm{~g}$ body weight; $P=0 \cdot 30$ ) or during pregnancy (Table 1$)$. In addition, nicotine exposure did not affect mating success (100\% in all groups), maternal weight gain during pregnancy, litter size, or birth weight in any treatment group (Table 1).

\section{Glucose homeostasis}

At 26 weeks of age, nicotine exposure had no effect on fasting serum glucose concentrations $(P>0 \cdot 05)$ or insulin concentrations (Kruskal-Wallis one-way ANOVA on ranks; $P>$ $0 \cdot 05$ ) in any treatment group (Table 2). Following an oral glucose challenge, animals in group $\mathrm{C}$ (fetal and neonatal nicotine exposure) had a higher total glucose response (AUC) to the glucose load relative to the saline controls $(P<0 \cdot 01)$, an effect that was not observed in any other group (Fig. 1). Furthermore, the peak glucose concentration at $30 \mathrm{~min}$ was higher in this group (saline $9.1 \pm 0.29 \mathrm{mmol} / \mathrm{l}$; group C $10 \cdot 9 \pm 1 \cdot 15 \mathrm{mmol} / \mathrm{l} ; P<0 \cdot 05)$ and the ability to clear the glucose load, determined by serum glucose concentrations at $120 \mathrm{~min}$ following the glucose challenge, was impaired (saline $8 \cdot 2 \pm 0.33 \mathrm{mmol} / 1$; group C $11.4 \pm 1 \cdot 21 \mathrm{mmol} / 1 ; P<0 \cdot 05$; Fig. 1). The total insulin response (AUC) to the glucose challenge was also elevated $(P<0 \cdot 05)$ in the offspring in

Table 1 Pregnancy outcome and birth phenotype. Values are presented as mean \pm S.E.M.

\section{Maternal food consumption ( $\mathrm{g}$ food/100 g body weight)}

\section{Treatment}

Saline

Nicotine group A/D

Nicotine group B/C

$\begin{array}{ll}7 \cdot 9 \pm 0 \cdot 10 & 138 \cdot 4 \pm 7 \cdot 30 \\ 7 \cdot 9 \pm 0 \cdot 14 & 160 \cdot 6 \pm 12 \cdot 66 \\ 8 \cdot 1 \pm 0 \cdot 24 & 130 \cdot 4 \pm 10 \cdot 05\end{array}$

Birth weight $(g)$

$6 \cdot 0 \pm 0 \cdot 06$

$5 \cdot 9 \pm 0 \cdot 04$

$6 \cdot 2 \pm 0 \cdot 09$
Litter size

$13 \cdot 8 \pm 0 \cdot 97$

$15 \cdot 1 \pm 0 \cdot 88$

$12 \cdot 0 \pm 1 \cdot 07$

Results for groups A and D and groups B and C were combined as pups in these groups had the same exposure to nicotine (preconceptual only and preconceptual + fetal exposure respectively). 
Table 2 Effect of developmental exposure to nicotine in Wistar rats. Values are presented as mean \pm S.E.M.

Fasting glucose $(\mathrm{mmol} / \mathrm{l})$

Treatment

Saline

Nicotine group A

Nicotine group B

Nicotine group $C$

Nicotine group D
Fasting insulin $(\mathrm{ng} / \mathrm{ml})$

$1 \cdot 9 \pm 0 \cdot 68$

$2 \cdot 0 \pm 0 \cdot 54$

$1 \cdot 4 \pm 0 \cdot 24$

$1 \cdot 8 \pm 0 \cdot 18$

$1 \cdot 5 \pm 0.31$
Insulin:glucose

$0 \cdot 27 \pm 0 \cdot 063$

$0 \cdot 24 \pm 0 \cdot 050$

$0 \cdot 19 \pm 0.030$

$0 \cdot 26 \pm 0.014$

$0 \cdot 21 \pm 0.048$

\section{AUC insulin}

$221 \cdot 8 \pm 27 \cdot 23$

$300 \cdot 2 \pm 50 \cdot 02$

$250 \cdot 2 \pm 38 \cdot 70$

$342 \cdot 2 \pm 40 \cdot 32 *$

$255.9 \pm 31.88$

Values with an asterisk are significantly different from the saline controls $(P<0 \cdot 05)$.

group C relative to the control (saline-exposed) offspring (Table 2).

\section{$\beta$-Cell mass}

At birth (PND1), results for groups A and D and groups B and $\mathrm{C}$ were combined as pups in these groups had the same exposure to nicotine (preconceptual only and preconceptual + fetal exposure respectively). Fetal exposure to nicotine (groups $\mathrm{B}$ and $\mathrm{C}$ ) resulted in reduced $\beta$-cell mass $(P<0 \cdot 05)$ relative to saline-exposed offspring (Fig. 2A), an effect that was still present at 4 weeks of age (Fig. 2B). By 26 weeks, animals exposed to nicotine during pregnancy alone (group B) had recovered their $\beta$-cell mass relative to saline controls (Fig. 2C). The $\beta$-cell mass at 26 weeks of offspring exposed to nicotine during both fetal and neonatal development (group C) continued to be lower than the $\beta$-cell mass of any other group (Fig. 2C). Offspring of dams exposed to nicotine prior to pregnancy or prior to pregnancy and during lactation (groups $\mathrm{A}$ and $\mathrm{D}$ respectively) did not exhibit a loss of $\beta$-cell mass at any age examined (Fig. 2A-C). At all the three ages, changes in $\beta$-cell mass were a reflection of changes in the $\beta$-cell area, not a reduction in pancreas weight (Table 3 ).
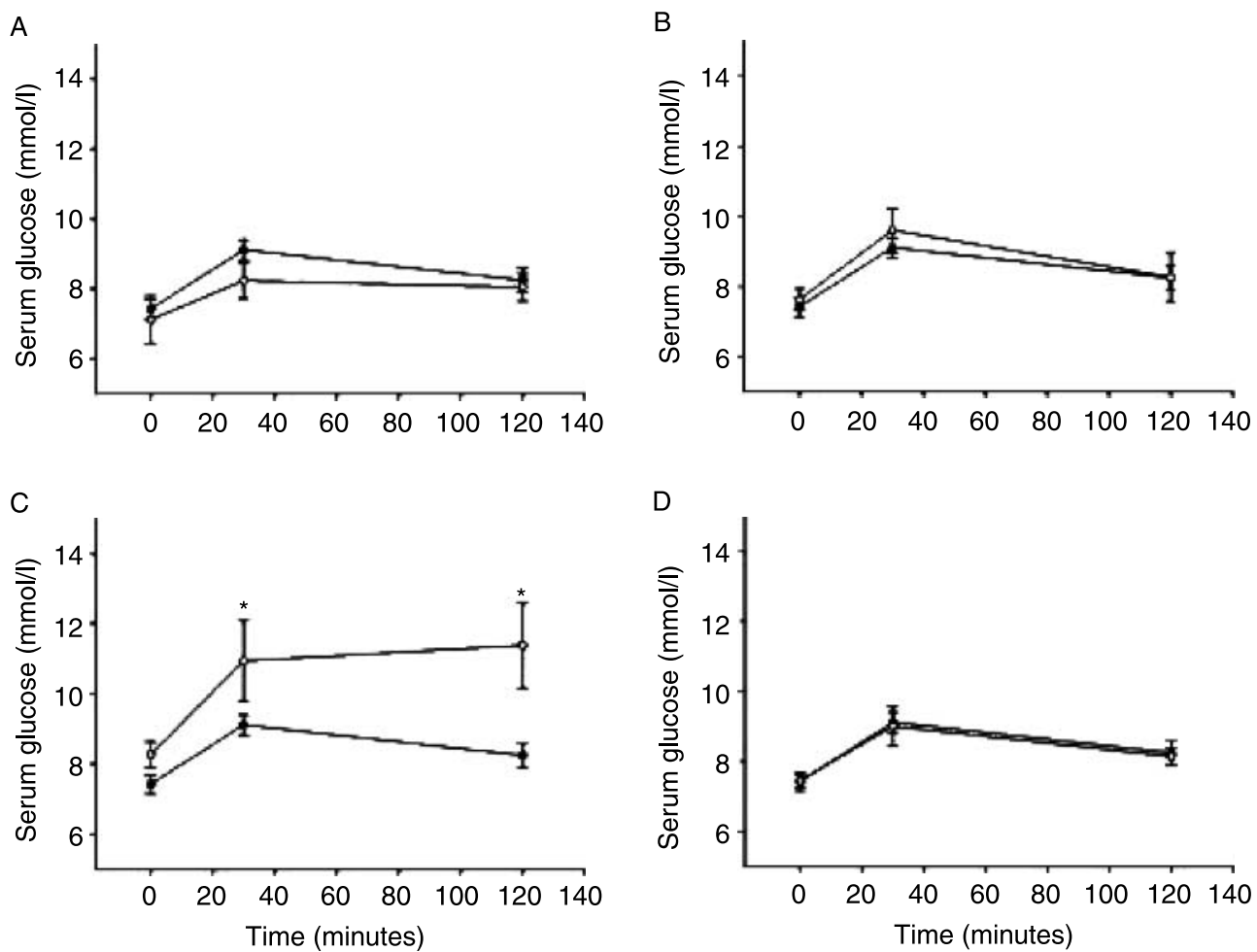

Figure 1 Serum glucose concentrations (mmol/l) following administration of an oral glucose load ( $2 \mathrm{~g} / \mathrm{kg}$ body weight) at 26 weeks of age for the offspring of female Wistar rats given saline (control, closed circles) or nicotine (1 mg/kg per day, open circles): (A) prior to pregnancy (group A); (B) prior to pregnancy and during pregnancy (group B); (C) prior to pregnancy, during pregnancy and during lactation (group C); and (D) prior to pregnancy and during lactation (group D); $n=12$ per group. Data are presented as mean \pm s.E.M. Values with an asterisk are significantly different from the saline controls $(P<0 \cdot 05)$. 

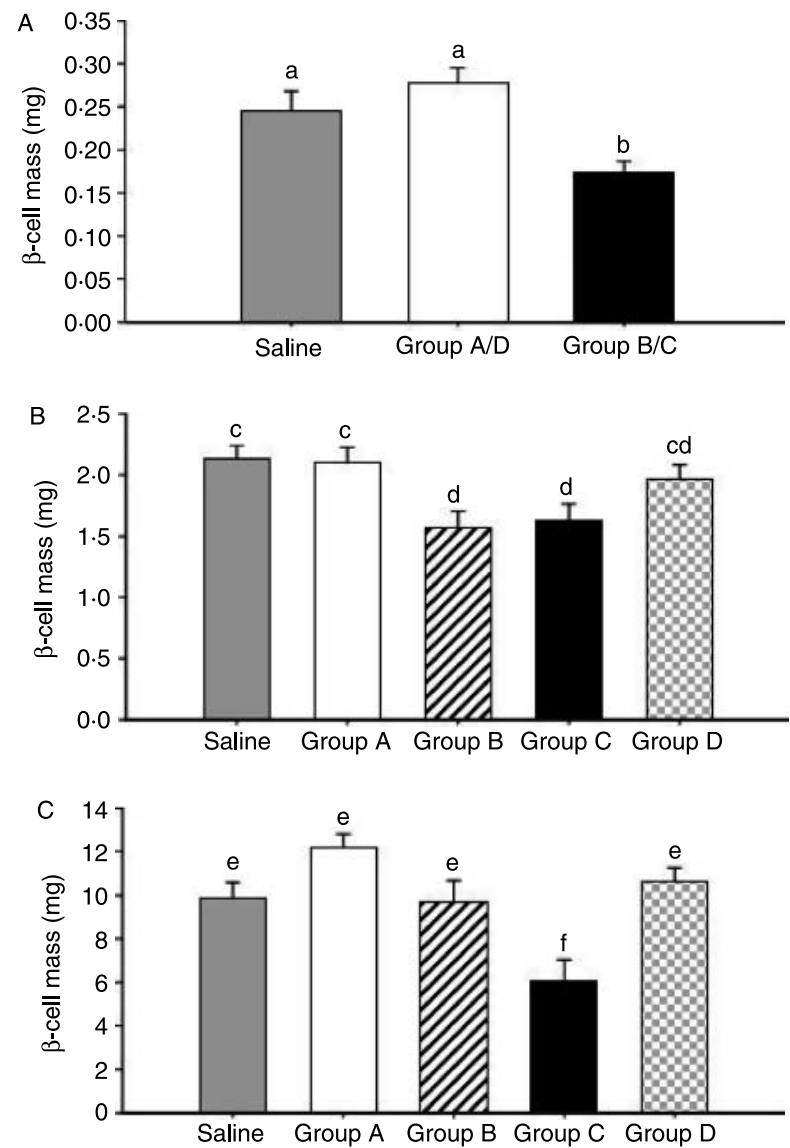

Figure 2 Effect of fetal and neonatal exposure to nicotine bitartrate $(1 \mathrm{mg} / \mathrm{kg}$ per day) on pancreatic $\beta$-cell mass $(\mathrm{mg})$ of rats at: $(\mathrm{A})$ PND1; (B) 4 weeks of age; and (C) 26 weeks of age. $\beta$-Cell mass was calculated using $n=5$ sections per animal, and $n=5$ animals per treatment group. Data are presented as mean \pm S.E.M. Values with different superscripts are significantly different from each other $(P<0 \cdot 05)$.

\section{$\beta$-Cell proliferation and apoptosis}

Although $\beta$-cell mass at 4 weeks of age was reduced in animals with fetal exposure alone or both fetal and neonatal exposure to nicotine, by 26 weeks of age the $\beta$-cell mass of animals without neonatal exposure (group B) was the same as saline controls, but remained suppressed in animals exposed during fetal and neonatal periods (group C). To determine whether this recovery was due to increased proliferation and/or decreased apoptosis in pancreatic islets, further studies were undertaken. At 4 weeks of age, animals in group B (fetal exposure only) had a higher percentage of $\mathrm{PCNA}^{+}$islet cells relative to the animals that had been exposed to nicotine during fetal and neonatal development (group C) and saline controls (Fig. 3A). Animals with fetal and neonatal exposure to nicotine (group C) had an increased level of $\beta$-cell apoptosis relative to those with fetal exposure alone or to saline controls (Fig. 3B).

\section{Discussion}

Our laboratory has previously demonstrated that nicotine exposure during pregnancy and lactation results in endocrine and metabolic changes in the offspring that are consistent with those observed in type 2 diabetes (Holloway et al. 2005). The dose of nicotine used in this study $(1 \mathrm{mg} / \mathrm{kg}$ per day nicotine bitartrate) results in maternal serum cotinine concentrations of $136 \mathrm{ng} / \mathrm{ml}$ (Holloway et al. 2006), which is within the range of cotinine levels $(80-163 \mathrm{ng} / \mathrm{ml})$ reported in women who are considered as 'moderate smokers' (Eskenazi \& Bergmann 1995). In addition, this dose of nicotine resulted in serum cotinine concentrations of $26 \mathrm{ng} / \mathrm{ml}$ in the nicotineexposed offspring at birth (Holloway et al. 2006), which is also within the range $(5-30 \mathrm{ng} / \mathrm{ml})$ observed in infants nursed by smoking mothers (Luck \& Nau 1985). Although 15-20\% of pregnant women smoke (Andres \& Day 2000, Okuyemi et al. 2000), many women attempt to stop smoking during pregnancy and then relapse following parturition (McBride \& Pirie 1990, Castrucci et al. 2006, Thyrian et al. 2006), resulting in nicotine exposure at conception and during lactation only. The influence this pattern may have on offspring health is unknown, as the developmental stages of fetal and neonatal development, which are susceptible to nicotine exposure, have not been determined. The present study was designed to represent the various windows of exposure that children of average smokers would experience. Since nicotine is rapidly metabolized in rats (half life of $45 \mathrm{~min}$ ), the nicotine from each daily injection is entirely cleared before the next injection (Matta et al. 2007), ensuring that each window of nicotine exposure remains separate. In this study, we have demonstrated, in an animal model, that postnatal glucose homeostasis is impaired only if nicotine exposure occurs during both pregnancy and lactation. Neither developmental stage alone leads to subsequent dysglycemia at 26 weeks of age in adult rat offspring. The impaired glucose homeostasis observed in this animal model is an early indicator of risk for the development of type 2 diabetes, a disease which is associated with numbers of comorbidities, including cardiovascular disease, nephropathy, retinopathy, and neuropathy (Clemens et al. 2004, Mlinar et al. 2007)

In humans, type 2 diabetes develops due to a progressive reduction in the ability of the pancreas to produce sufficient insulin to compensate for any underlying resistance to the action of insulin (Lindley et al. 2000, Kahn 2003, Leahy 2005). This defect in $\beta$-cell function is already observed in dysglycemic individuals with impaired fasting glucose or impaired glucose tolerance, long before the onset of frank type 2 diabetes (Kahn 2003). Recent studies suggest that this insulin insufficiency may be due, in part, to a reduction in $\beta$-cell mass (Leahy 2005, Rhodes 2005). Indeed, in humans, pancreatic $\beta$-cell mass is reduced by $40-60 \%$ in patients with type 2 diabetes (Lindley et al. 2000, Sakuraba et al. 2002, Yoon et al. 2003), and this reduction in $\beta$-cell mass precedes the 
Table 3 Effect of developmental exposure to nicotine on $\beta$-cell mass in Wistar rats. Values are presented as mean \pm S.E.M.

\section{Treatment}

Age

PND 1

4 weeks $\beta$-cell area $(\%)$

$$
\begin{gathered}
2 \cdot 0 \pm 0 \cdot 18 \\
2 \cdot 0 \pm 0 \cdot 12 \\
1 \cdot 4 \pm 0 \cdot 12^{*} \\
0 \cdot 7 \pm 0 \cdot 04 \\
0 \cdot 6 \pm 0 \cdot 04 \\
0 \cdot 4 \pm 0 \cdot 04^{*} \\
0 \cdot 5 \pm 0 \cdot 04^{*} \\
0 \cdot 7 \pm 0 \cdot 04 \\
1 \cdot 2 \pm 0 \cdot 06 \\
1 \cdot 3 \pm 0 \cdot 06 \\
0 \cdot 90 \pm 0 \cdot 05 \\
0 \cdot 64 \pm 0 \cdot 03^{*} \\
1 \cdot 2 \pm 0 \cdot 07
\end{gathered}
$$

Pancreas mass $(\mathrm{mg})$

$\boldsymbol{\beta}$-cell mass (mg)

$0 \cdot 24 \pm 0 \cdot 023$

$0 \cdot 28 \pm 0 \cdot 017$

$0 \cdot 17 \pm 0 \cdot 013^{*}$

$2 \cdot 13 \pm 0 \cdot 11$

$2 \cdot 09 \pm 0 \cdot 14$

$1 \cdot 57 \pm 0 \cdot 14^{*}$

$1 \cdot 62 \pm 0.14^{*}$

$1.96 \pm 0.12$

$9 \cdot 83 \pm 0 \cdot 76$

$12 \cdot 17 \pm 0 \cdot 64$

$9 \cdot 66 \pm 1 \cdot 02$

$6 \cdot 09 \pm 0 \cdot 95^{*}$

$10 \cdot 65 \pm 0 \cdot 61$

At birth (PND1), results for groups A and D and groups B and C were combined, as pups in these groups had the same exposure to nicotine (preconceptual only and preconceptual + fetal exposure respectively). Values with an asterisk are significantly different from the saline controls $(P<0 \cdot 05)$.

diagnosis of diabetes (Lindley et al. 2000). Similarly, we have shown in an animal model that reduced $\beta$-cell mass preceded the loss of normal glycemic control, and that although insulin
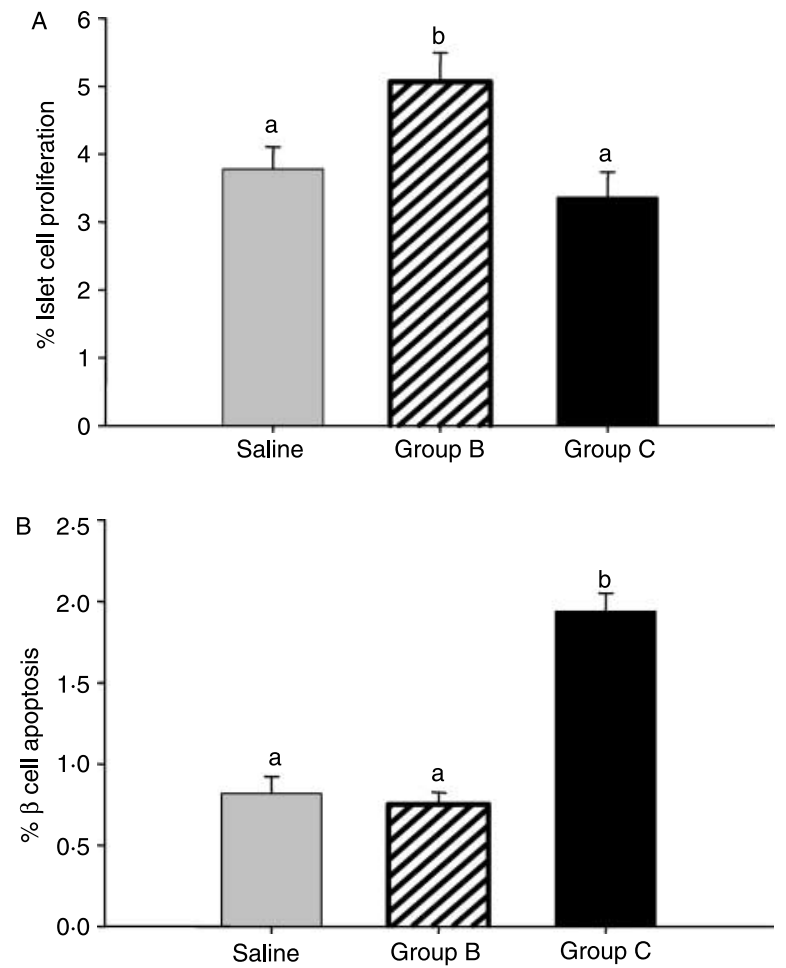

Figure 3 Effect of fetal exposure only (group B), and fetal and lactational exposure (group $\mathrm{C})$ to nicotine bitartrate $(1 \mathrm{mg} / \mathrm{kg}$ per day) on: (A) percentage of islet cell proliferation $\left(\mathrm{PCNA}^{+}\right.$islet cells) and (B) percentage of $\beta$-cell apoptosis ( $\mathrm{TUNEL}^{+} \beta$-cells) at 4 weeks of age. Both apoptosis and proliferation were calculated using $n=3$ islets per section, with $n=3$ sections per animal and $n=5$ animals per group. Data are presented as mean \pm S.E.M. Values with different superscripts are significantly different from each other $(P<0 \cdot 01)$. secretion in response to the OGTT was increased, it was insufficient to normalize glucose concentrations, an effect which is in accordance with our previous findings (Holloway et al. 2005).

We had previously suggested that nicotine-induced damage to the $\beta$-cell during fetal development may induce permanent changes in pancreatic structure and function evident as impaired glycemia in adults (Holloway et al. 2005). Similar findings have been reported for other in utero insults, including glucocorticoid administration, uteroplacental insufficiency, and fetal undernutrition (Petrik et al. 1999, Holness et al. 2000, Simmons et al. 2001, Shen et al. 2003). However, this work illustrates that in utero nicotine exposure alone transiently reduces $\beta$-cell mass without permanent metabolic defects. The full recovery of $\beta$-cell mass and function can be attributed to enhanced $\beta$-cell proliferation leading to increased expansion of $\beta$-cell mass between 1 and 6 months of age. Control animals experienced a $4 \cdot 6$-fold increase in $\beta$-cell mass between 1 and 6 months of age, whereas animals with fetal exposure only (group B) had lower absolute $\beta$-cell mass at 1 month of age but a $6 \cdot 2$-fold 'catch-up' in $\beta$-cell mass, such that by 26 weeks of age they had recovered to $98 \%$ of the saline control $\beta$-cell mass. There was no decrease in apoptosis found to explain this 'catch up' in $\beta$-cell mass. Continued nicotine exposure through lactation appears to prevent this pancreatic cell 'catch up'. The rats exposed to nicotine during both fetal and neonatal development had a $\beta$-cell mass that was only $62 \%$ of controls at 26 weeks of age. Furthermore, the inhibited growth of $\beta$-cell mass in these offspring was due to increased $\beta$-cell apoptosis and not due to decreased $\beta$-cell proliferation.

Other insults during fetal and neonatal development, such as maternal undernutrition, also cause a reduction in the $\beta$-cell mass at birth, an effect which was irreversible even though restoration of nutrition at the end of gestation resulted in normal $\beta$-cell proliferation during lactation (Garofano et al. 
1997). In contrast, the results from this study have demonstrated that increased $\beta$-cell replication following a reduction in $\beta$-cell mass at birth was able to fully restore $\beta$-cell mass and function. However, recovery occurred only when nicotine exposure was stopped prior to neonatal pancreatic development. When nicotine exposure continued through neonatal pancreatic development via lactation (group C animals), the capacity for islet cell proliferation and, therefore, $\beta$-cell recovery appears to be lost. These results are also consistent with another rodent model, in which the primary mechanisms for an adaptive increase in $\beta$-cell mass were islet neogenesis and $\beta$-cell replication, while an adaptive reduction in $\beta$-cell mass was primarily due to increased $\beta$-cell apoptosis (Butler et al. 2003).

In conclusion, nicotine exposure during both pregnancy and lactation results in impaired glucose homeostasis in the offspring of this animal model. This effect is mediated by an irreversible reduction in pancreatic $\beta$-cell mass in early life. These results confirm the previous findings that recovery of $\beta$-cell mass occurs during critical developmental windows, otherwise the $\beta$-cell loss is permanent and will lead to metabolic defects in the offspring. In applying these results to the human population, it is essential to consider the developmental differences between species. In rats, pancreatic development occurs both prenatally and postnatally, whereas in humans, the majority of development is completed prenatally (Hill \& Duvillie 2000). However, regardless of the differences in timing, the essential principle that impairment of early pancreatic development will result in permanent changes remains the same. Therefore, data from the present study imply that smoking cessation prior to the completion of pancreatic development may be beneficial in terms of protecting the future metabolic capacity of the offspring. This study also raises some concerns regarding the safety of continuous nicotine replacement therapy during pregnancy and lactation.

\section{Acknowledgements}

This work was supported by an operating grant from the Canadian Institutes of Health Research in Nutrition, Metabolism and Diabetes to A C H and K M M (MOP 69 025), and a fellowship from the Heart and Stroke Foundation to K M M. J E B was funded by the CIHR Strategic Training Program in Tobacco Research Fellowship and an Ontario Graduate Scholarship. H C G holds the Population Health Institute Chair in Diabetes Research (sponsored by Aventis). We thank Ms Sandra Stals, Mr Ed Hadzocos, and the staff of the McMaster University Central Animal Facility for their assistance with the animal work and Dr Jim Petrik for his assistance with the image analysis. The authors declare that there is no conflict of interest that would prejudice the impartiality of this scientific work.

\section{References}

Andres RL \& Day MC 2000 Perinatal complications associated with maternal tobacco use. Seminars in Neonatology 5 231-241.

Bergmann KE, Bergmann RL, Von KR, Bohm O, Richter R, Dudenhausen JW \& Wahn U 2003 Early determinants of childhood overweight and adiposity in a birth cohort study: role of breast-feeding. International Journal of Obesity and Related Metabolic Disorders 27 162-172.

Blake KV, Gurrin LC, Evans SF, Beilin LJ, Landau LI, Stanley FJ \& Newnham JP 2000 Maternal cigarette smoking during pregnancy, low birth weight and subsequent blood pressure in early childhood. Early Human Development 57 137-147.

Butler AE, Janson J, Soeller WC \& Butler PC 2003 Increased beta-cell apoptosis prevents adaptive increase in beta-cell mass in mouse model of type 2 diabetes: evidence for role of islet amyloid formation rather than direct action of amyloid. Diabetes 52 2304-2314.

Castrucci BC, Culhane JF, Chung EK, Bennett I \& McCollum KF 2006 Smoking in pregnancy: patient and provider risk reduction behavior. Journal of Public Health Management and Practice 12 68-76.

Cleasby ME, Kelly PA, Walker BR \& Seckl JR 2003 Programming of rat muscle and fat metabolism by in utero overexposure to glucocorticoids. Endocrinology 144 999-1007.

Clemens A, Siegel E \& Gallwitz B 2004 Global risk management in type 2 diabetes: blood glucose, blood pressure, and lipids - update on the background of the current guidelines. Experimental and Clinical Endocrinology and Diabetes 112 493-503.

Eskenazi B \& Bergmann JJ 1995 Passive and active maternal smoking during pregnancy, as measured by serum cotinine, and postnatal smoke exposure. I. Effects on physical growth at age 5 years. American Journal of Epidemiology 142 S10-S18.

Gao YJ, Holloway AC, Zeng ZH, Lim GE, Petrik JJ, Foster WG \& Lee RM 2005 Prenatal exposure to nicotine causes postnatal obesity and altered perivascular adipose tissue function. Obesity Research 13 687-692.

Garofano A, Czernichow P \& Breant B 1997 In utero undernutrition impairs rat beta-cell development. Diabetologia 40 1231-1234.

Hill DJ \& Duvillie B 2000 Pancreatic development and adult diabetes. Pediatric Research 48 269-274.

Hofhuis W, de Jongste JC \& Merkus PJ 2003 Adverse health effects of prenatal and postnatal tobacco smoke exposure on children. Archives of Disease in Childhood 88 1086-1090.

Holloway AC, Lim GE, Petrik JJ, Foster WG, Morrison KM \& Gerstein HC 2005 Fetal and neonatal exposure to nicotine in Wistar rats results in increased beta cell apoptosis at birth and postnatal endocrine and metabolic changes associated with type 2 diabetes. Diabetologia 48 2661-2666.

Holloway AC, Kellenberger LD \& Petrik JJ 2006 Fetal and neonatal exposure to nicotine disrupts ovarian function and fertility in adult female rats. Endocrine 30 213-216.

Holness MJ, Langdown ML \& Sugden MC 2000 Early-life programming of susceptibility to dysregulation of glucose metabolism and the development of type 2 diabetes mellitus. Biochemical Journal 349 657-665.

Kahn SE 2003 The relative contributions of insulin resistance and beta-cell dysfunction to the pathophysiology of type 2 diabetes. Diabetologia 46 3-19.

Lambers DS \& Clark KE 1996 The maternal and fetal physiologic effects of nicotine. Seminars in Perinatology 20 115-126.

Leahy JL 2005 Pathogenesis of type 2 diabetes mellitus. Archives of Medical Research 36 197-209.

Lindley AA, Becker S, Gray RH \& Herman AA 2000 Effect of continuing or stopping smoking during pregnancy on infant birth weight, crown-heel length, head circumference, ponderal index, and brain:body weight ratio. American Journal of Epidemiology 152 219-225.

Luck W \& Nau H 1985 Nicotine and cotinine concentrations in serum and urine of infants exposed via passive smoking or milk from smoking mothers. Journal of Pediatrics 107 816-820.

Matta SG, Balfour DJ, Benowitz NL, Boyd RT, Buccafusco JJ, Caggiula AR, Craig CR, Collins AC, Damaj MI, Donny EC et al. 2007 Guidelines on nicotine dose selection for in vivo research. Psychopharmacology 190 269-319. 
McBride CM \& Pirie PL 1990 Postpartum smoking relapse. Addictive Behaviors 15 165-168.

Mlinar B, Marc J, Janez A \& Pfeifer M 2007 Molecular mechanisms of insulin resistance and associated diseases. Clinica Chimica Acta 375 20-35.

Montgomery SM \& Ekbom A 2002 Smoking during pregnancy and diabetes mellitus in a British longitudinal birth cohort. BMJ 324 26-27.

Morley R, Leeson PC, Lister G \& Lucas A 1995 Maternal smoking and blood pressure in $7 \cdot 5$ to 8 year old offspring. Archives of Disease in Childhood 72 $120-124$.

Newman MB, Shytle RD \& Sanberg PR 1999 Locomotor behavioral effects of prenatal and postnatal nicotine exposure in rat offspring. Behavioural Pharmacology 10 699-706.

Okuyemi KS, Ahluwalia JS \& Harris KJ 2000 Pharmacotherapy of smoking cessation. Archives of Family Medicine 9 270-281.

Pausova Z, Paus T, Sedova L \& Berube J 2003 Prenatal exposure to nicotine modifies kidney weight and blood pressure in genetically susceptible rats: a case of gene-environment interaction. Kidney International 64 829-835.

Petrik J, Reusens B, Arany E, Remacle C, Coelho C, Hoet JJ \& Hill DJ 1999 A low protein diet alters the balance of islet cell replication and apoptosis in the fetal and neonatal rat and is associated with a reduced pancreatic expression of IGF-II. Endocrinology 140 4861-4873.

Pickett KE, Wakschlag LS, Dai L \& Leventhal BL 2003 Fluctuations of maternal smoking during pregnancy. Obstetrics and Gynecology 101 140-147.

Pratley RE \& Weyer C 2001 The role of impaired early insulin secretion in the pathogenesis of type II diabetes mellitus. Diabetologia 44 929-945.

Rhodes CJ 2005 Type 2 diabetes-a matter of beta-cell life and death? Science 307 380-384.

Sakuraba H, Mizukami H, Yagihashi N, Wada R, Hanyu C \& Yagihashi S 2002 Reduced beta-cell mass and expression of oxidative stress-related DNA damage in the islet of Japanese type II diabetic patients. Diabetologia 45 85-96.

Shen CN, Seckl JR, Slack JM \& Tosh D 2003 Glucocorticoids suppress betacell development and induce hepatic metaplasia in embryonic pancreas. Biochemical Journal 375 41-50.
Simmons RA, Templeton LJ \& Gertz SJ 2001 Intrauterine growth retardation leads to the development of type 2 diabetes in the rat. Diabetes 50 2279-2286.

Thyrian JR, Hannover W, Roske K, Rumpf HJ, John U \& Hapke U 2006 Postpartum return to smoking: identifying different groups to tailor interventions. Addictive Behaviors 31 1785-1796.

Toschke AM, Koletzko B, Slikker W Jr, Hermann M \& Von KR 2002 Childhood obesity is associated with maternal smoking in pregnancy. European Journal of Pediatrics 161 445-448.

Vik T, Jacobsen G, Vatten L \& Bakketeig LS 1996 Pre- and post-natal growth in children of women who smoked in pregnancy. Early Human Development 45 245-255.

Von KR, Toschke AM, Koletzko B \& Slikker W Jr 2002 Maternal smoking during pregnancy and childhood obesity. American Journal of Epidemiology 156 954-961.

Wideroe M, Vik T, Jacobsen G \& Bakketeig LS 2003 Does maternal smoking during pregnancy cause childhood overweight? Paediatric and Perinatal Epidemiology 17 171-179.

Williams CM \& Kanagasabai T 1984 Maternal adipose tissue response to nicotine administration in the pregnant rat: effects on fetal body fat and cellularity. British Journal of Nutrition 51 7-13.

Yoon KH, Ko SH, Cho JH, Lee JM, Ahn YB, Song KH, Yoo SJ, Kang MI, Cha BY, Lee KW et al. 2003 Selective beta-cell loss and alpha-cell expansion in patients with type 2 diabetes mellitus in Korea. Journal of Clinical Endocrinology and Metabolism 88 2300-2308.

\section{Received in final form 12 April 2007 \\ Accepted 17 April 2007}

Made available online as an Accepted Preprint 18 April 2007 